\title{
Concerns About own Security Among Police Officers in Relation to Some Demographic Factors
}

\author{
Emelina Valentinova Zaimova - Tsaneva \\ South-West University "Neofit Rilski”, Blagoevgrad, BULGARIA \\ Department of Psychology
}

Received: 7 July 2021 - Accepted: 28 August 2021 • Published Online: 10 September 2021

\begin{abstract}
The research demonstrates that working in the field of civil security is a stressful and dangerous occupation which determinates negative impact on police officers' experienced level of own security, which grows into concerns about own security. The examination of concerns about own security included 264 police officers (Mean $=36.11$ ). Women have higher values of concerns about their own security (Mean=38.86), than men (Mean=34.67). Police officers who lived in the capital have higher concerns about own security $(M R=149.10)$. The correlation analysis shows a weak proportional relationship between age and concerns about own security among police officers $(\mathrm{r}=0.146 ; \mathrm{p}=0.018)$.
\end{abstract}

Keywords: Concerns, security, fear of crime, police officers.

\section{Introduction}

Law enforcement activity and its responsibility place many and varied demands on the individual police officers. They are expected to remain calm despite the danger, scorn, ridicule, or demonstration of "respect" and impose themselves restraint and goodwill, thinking about others' well-being (Ganchevski et al., 1996). The main roles of the police are fighting with and preventing crime, upholding the law, bringing to justice those who break the law and protecting, helping, and reassuring the community (Button, 1999). When they solve professional issues or in situations related to official activities, the problem of own security of police officers is currently gaining particular relevance and importance. The risk, both physical and psychological, is an objective component in law enforcement officers' professional activities.

The specifics of police officers' professional activities are mainly related to the fight against crime and the protection of public order. One characteristic of the profession is the presence of many stressors. The conditions under which the professional activities are carried out, are dynamic, changeable, and carry tremendous potential risk for the employees' health and life (Ganchevski et al., 1996). Given the current characteristics of society, it can be argued that the work of police officers is extremely difficult, dangerous, and stressful. They operate in an environment full of uncertainty and danger, linked to the constant threat of crime, terrorist attacks, growing use of firearms in urban areas, low human and material resources, difficulties in teams or supervision processes, criticism from citizens and society, and lack of understanding from family or friends (Queirós et al., 2020). At the same time, high levels of unemployment, rising

(C) Authors. Terms and conditions of Creative Commons Attribution 4.0 International (CC BY 4.0) apply. Correspondence: Emelina Valentinova Zaimova - Tsaneva, South-West University "Neofit Rilski", Department of Psychology, Blagoevgrad, BULGARIA. E-mail: emelina z@swu.bg. 
E. V. Zaimova - Tsaneva - Concerns About own Security Among Police Officers in Relation to ...

domestic crime and its ineffective prevention create preconditions for an increased sense of insecurity for the health, life, and property of police officers, both as citizens and as professionals.

For solving the problem of preserving the health and professional longevity of the police officers, a purposeful management policy is needed to ensure their own security. To achieve this goal, police officers must create the necessary conditions to carry out the tasks, assigned to them. They should preserve public order and protect their colleagues, citizens, buildings, premises, documents, weapons, ammunition, and unique means from criminal encroachments by the actions of criminal communities and persons who pose a threat to their own security, prevention, and localization of the negative consequences of these actions.

The importance of psychological research on tendencies and peculiarities in examining concerns about own security among police officers is reflected in the need to update psychological methods and strategies to deal with fear, worry anxiety, depression, stress, and burnout as related phenomena.

\section{Definition of concerns about own security}

When studying the reactions to a threat to about own security, anxiety is traditionally in the focus of the psychology research. At the same time, there are not so many researches on the study of concerns about own security among police officers. It is considered in the framework of studying the personal safety of employees or in the context of extreme, emergency situations, etc. It is an emotional reaction or emotional state. At the individual level, people's reactions are expressed in increased caution, increased anxiety, and experiences of fear in certain situations. However, when people think about their security, they do not necessarily experience negative emotions. Most often, they take various actions to prevent the occurrence of such experiences. The consequences of this are diverse - increased expenses for the protection of their own homes and property, proliferation of weapons for self-defense, limiting the public activity of citizens in certain places and at certain times of the day, changes in economic behavior (Radoslavova \& Velichkov, 1999).

The literature analysis made it possible to present the interpretation of "concerns about own security" as spontaneous thoughts, mostly with verbal content (but not necessary), about potential dangers and unpleasant events that can cause negative emotional experiences (Borkovec, 1994; Borkovec et al., 1998).

\section{Mental phenomena similar to concern about own security}

A phenomenon, which is connected with concern, is "worry" (Wells, 2004; Borkovec, 1994; Borkovec et al., 1998). According to APA Dictionary of Psychology (2021) worry is a "mental distress or agitation resulting from concern usually for something impending or anticipated" (APA Dictionary of Psychology, 2021). Worry can be defined as repetitive, uncontrollable thoughts about potential negative life events (Segerstrom et al., 2000; Roemer \& Borkovec, 1993). NolenHoeksema, Wisco and Lyubomirsky (2008) suggested that worry is future-oriented and focuses on threats that have not yet occurred. Worry is a key feature of generalized anxiety disorder (GAD; American Psychiatric Association, 2013) such as negative automatic thoughts (Flouri \& Panourgia, 2014).

Many researches are focused specifically on the anxiety (Hasain, 2019; Wagner et al., 2019) and professional stress of police officers (e.g., Agolla, 2009; Galanis et al., 2019; Johnson et al., 2019), while others have investigated police officers' burnout (e.g., Queirós et al., 2020; Aguayo et al., 2017; Adams \& Mastracci, 2019). Anxiety is a central explanatory concept repeatedly and thoroughly studied and can be found in almost all contemporary theories of personality. Moreover, 
anxiety is regarded as a principal causative agent for such diverse behavioral consequences as insomnia, immoral and disgraceful acts, instances of creative self-expression, debilitating psychological and psychosomatic symptoms, and specific mannerisms (Spielberger, 2013). It can be defined as an emotion characterized by apprehension and somatic symptoms of tension in which an individual anticipates impending danger, catastrophe, or misfortune (VandenBos, 2015). It can generally be divided into pathological and nonclinical. Beck and Clark (1997) believe that difference is that in pathological anxiety there is a biased or overestimated perception of danger, which does not correspond to the exigencies of the internal or external environment, whereas in nonclinical anxiety states the estimation of threat corresponds more closely to the objective dangers in the environment.

Anxiety may be differentiated from fear both on a conceptual and physiological level, although the two terms are often used interchangeably. Anxiety is considered a future-oriented, long-acting response broadly focused on a diffuse threat. In contrast, fear is an appropriate, present-oriented, and short-lived response to a recognizable and specific threat (VandenBos, 2015).

Other specific phenomenon, which are very close to concerns about own security are the concern of crime and fear of crime. Fear of crime can be defined as an emotional response to possible violent crime and physical harm (Covington \& Taylor, 1991). While concern about crime can be seen as positive, as it encourages people to take precautions against victimization, "fear of crime may have adverse emotional effects on people, causing feelings of isolation and vulnerability. This often leads to significant losses in personal well-being" (Hale, 1996: 2).

\section{Security as a psychological construct}

The other part of the dyad "concern - security" is security itself. It can be defined as an internal state of calm and trust in the external environment, and the feeling of personal security is a more general experience of the possibilities to counteract in the event of a threat (Velichkov, 2004). In this sense, it is an important prerequisite for optimal organization and regulatory processes to achieve various goals and meet personal needs. Violation of the sense of personal security leads to the emergence of a stress response and directing regulatory processes to eliminate the threat (Folkman, 1984). Maintaining a state of security has a profound motivational basis and is associated with basic human needs - the need for safety (Maslow, 1987; Murray, 1981; Lazarus, 1991).

In the opinion of Zotova (2011) "psychological security is the state of an individual when he/she can satisfy his/her basic needs for self-preservation and perceive his/her own (psychological) shelteredness in socium” (Zotova \& Karpetyan, 2018: 103).

Zotova and Karapetyan (2018) assume that strategies associated with the provision of security are aimed at identifying and preventing threats. According to them, the main proposes are: (a) Protection of human life; (b) Protection of people from existing threats; (c) Provision of vital rights and freedoms for all people; (d) Creation of political, economic, social, and cultural conditions under which people can live knowing that their rights and freedoms are secured (Zotova \& Karpetyan, 2018). The sense of security is always subjective (Wendt, 1992).

\section{Need for safety}

According to Maslow's theory, there are five categories of human needs. It is well known as physiological, safety-security, belongingness, esteem, and self-actualization) (Maslow, 2002). The second one in this classification is the need for safety and security. It is considered one 
E. V. Zaimova - Tsaneva - Concerns About own Security Among Police Officers in Relation to ...

of the most important psychological needs, and it is the basis of personal well-being and mental health.

To understand the meaning of the safety-security needs, it is necessary to identify the types of threats that could provoke the safety-security response and the conditions that satisfy these needs. Because this level of need is conceptually higher than the previous level, the terms used as threats to safety refer to both concrete and abstract things. Such concerns about potential dangers could be wild animals, criminal assault, disease, war, anarchy, social chaos, natural catastrophes, and, in more peaceful times, the lack of such things as job security, financial security, medical insurance, and retirement security (Maslow, 1943).

Modern society has a relatively high level of real security. However, people still need more security and are watching for various possible dangers and threats (Zotova \& Karpetyan, 2018). When a person feels insecure in his environment, his psychological well-being decreases and he becames extremely sensitive to "future shock" (Toffler, 2002).

In this research, the focus is on concerns about own security in the context of a specific professional activity involving danger, responsibility, and stress, such as policing. Due to the specifics of the profession, it is logical for police officers to feel some concerns about their own security and depend on various internal and external circumstances. Personal safety is based on a sufficient level of professional training of workers (Ustinova \& Sultanova, 2018). This presupposes the possession of knowledge and skills for applying appropriate work methods, formed personal attitude to survival, psychological qualities that adequately assess the situation, make quick and correct decisions, and not lose control in dangerous situations.

\section{Method}

\subsection{Participants}

The survey involved 264 respondents. The results presented in Table 1 indicate that the majority of the respondents were men (58.3\%). The sample consisted of 110 women (41.7\%) The age of the respondents ranged from 25 to 58 years. The average age of the respondents was 41 years $(\mathrm{SD}=7.93)$, for women $43(\mathrm{SD}=8.036)$ and for men $39(\mathrm{SD}=7.605)$. Of the other demographic characteristics we surveyed, most respondents stated that they live in marriage $(\mathrm{n}=123 ; 46.6 \%)$, most respondents live in town $(\mathrm{n}=134 ; 50.8 \%)$, the second (master) degree of university education was also reported by the majority of respondents $(n=106 ; 40.2 \%)$. Convenience and purposive sampling method have been used.

Table 1. Social-demographic characteristics, number, and percentage of the participants divided into groups

\begin{tabular}{|c|c|c|}
\hline Characteristics & Total & $\%$ \\
\hline \multicolumn{3}{|l|}{ Sex } \\
\hline Male & 154 & 58.3 \\
\hline Female & 110 & 41.7 \\
\hline \multicolumn{3}{|l|}{ Education } \\
\hline Secondary & 66 & $25 \%$ \\
\hline Bachelor degree & 92 & 34.8 \\
\hline Master degree & 106 & 40.2 \\
\hline \multicolumn{3}{|l|}{ Place of residence } \\
\hline Village $</=5,000$ & 68 & 25.8 \\
\hline Town $</=100,000$ & 134 & 50.8 \\
\hline Capital & 62 & 23.5 \\
\hline \multicolumn{3}{|l|}{ Marital status } \\
\hline Single & 42 & 15.9 \\
\hline
\end{tabular}




$\begin{array}{lcc}\text { Cohabitation } & 72 & 27.3 \\ \text { Marriage } & 123 & 46.6 \\ \text { Divorced } & 27 & 10.2\end{array}$

\subsection{Instruments}

One paper-and-pencil questionnaire measuring the level of concerns about own security was used. Radoslavova and Velichkov (2005) created it in Bulgarian. The scale for assessing the level of concerns about own security consists 15 items and its Cronbach's alpha is 0.92. All the answers were given on a 5-point scale. The response alternatives were from $1-$ never to 5- very often (Radoslavova \& Velichkov, 2005). The socio-demographic data were also collected.

\subsection{Procedure}

The questionnaires were submitted to respondents in the period June 2020 - August 2020 Respondents were informed that completing the questionnaire is voluntary and anonymous and that data will only be processed in the framework of this research study. All respondents expressed their agreement to participate in the research. The collected data were analyzed in IBM SPSS Statistics 19.

There were no missing data in the dataset.

Applying descriptive statistics for establishing the frequency distributions of levels of concerns about own security. Independent T-Test, ANOVA and non-parametric test of KruskalWallis were used. Pearson correlation coefficient and connections between the studied variables.

\section{Results}

The examination of concerns about own security included 264 police officers. The average value of their concerns about own security is $36.11(\mathrm{SD}=10.08)$. The demographic statistics of the respondents are presented in Table 2 alongside the level of concerns about own security The results show that $58.3 \%$ from the surveyed police officers have middle level of concerns about own security, and $33.6 \%$ of them have high level. As a conclusion of these results, it can be argued that the bigger part of police officers who participated in the study have significant concerns about their own security.

Table 2. Levels of concerns about own security depending on demographic factors: Number and percentage

\begin{tabular}{|cccccccc|}
\hline Demographics & \multicolumn{2}{c}{ Low level } & \multicolumn{2}{c}{ Middle level } & \multicolumn{2}{c|}{$\begin{array}{c}\text { High } \\
\text { Level }\end{array}$} & Total \\
\hline Sex & $\mathrm{N}$ & $\%$ & $\mathrm{~N}$ & $\%$ & $\mathrm{~N}$ & $\%$ & $\mathrm{~N}$ \\
\hline Male & & & & & & & \\
Female & 11 & $4.2 \%$ & 93 & $35.2 \%$ & 50 & $18.9 \%$ & 154 \\
$\quad$ & 5 & $1.9 \%$ & 61 & $23.1 \%$ & 44 & $16.7 \%$ & 110 \\
Total & 16 & $6.1 \%$ & 154 & $58.3 \%$ & 94 & $35.6 \%$ & 264 \\
\hline Place of residence & & & & & & & \\
\hline Village </= 5,000 & 3 & $1.1 \%$ & 40 & $15.2 \%$ & 25 & $9.5 \%$ & 68 \\
$\quad$ Town </= 100,000 & 13 & $4.9 \%$ & 78 & $29.5 \%$ & 43 & $16.3 \%$ & 134 \\
Capital & 0 & $0 \%$ & 36 & $13.6 \%$ & 26 & $9.8 \%$ & 62 \\
$\quad$ Total & 16 & $6.1 \%$ & 154 & $58.3 \%$ & 94 & $35.6 \%$ & 264 \\
\hline Education & & & & & & & \\
\hline Secondary & 5 & $1.9 \%$ & 36 & $13.6 \%$ & 25 & $9.5 \%$ & 66 \\
Bachelor degree & 4 & $1.5 \%$ & 53 & $20.1 \%$ & 35 & $13.3 \%$ & 92
\end{tabular}


E. V. Zaimova - Tsaneva - Concerns About own Security Among Police Officers in Relation to ...

\begin{tabular}{|cccccccc|} 
Master degree & 7 & $2.7 \%$ & 65 & $24.6 \%$ & 34 & $12.9 \%$ & 106 \\
Total & 16 & $6.1 \%$ & 154 & $58.3 \%$ & 94 & $35.6 \%$ & 264 \\
\hline Marital status & & & & & & & \\
\hline Single & 3 & $1.1 \%$ & 27 & $10.2 \%$ & 12 & $4.5 \%$ & 42 \\
Cohabitation & 5 & $1.9 \%$ & 40 & $15.2 \%$ & 27 & $10.2 \%$ & 72 \\
Marriage & 8 & $3.0 \%$ & 72 & $27.3 \%$ & 43 & $16.3 \%$ & 123 \\
Divorced & 0 & $0 \%$ & 15 & $5.7 \%$ & 12 & $10.2 \%$ & 27 \\
Total & 16 & $6.1 \%$ & 154 & $58.3 \%$ & 94 & $35.6 \%$ & 264 \\
\hline
\end{tabular}

The results of the comparisons using Independent Simples T-Test for the statistic procedure showed significant differences between men and woman, who working as police officers in terms of concerns about their own security $(\mathrm{t}=2.785 ; \mathrm{p}=0.006)$ (Table 3$)$. In particular, it can be said that women have higher values of concerns about their own security (Mean $=38.86$ ), than men $($ Mean $=34.67)$.

Table 3. Results from independent simples t-test for finding significant differences in concerns about own security

\begin{tabular}{lcccccc}
\hline & Sex & M & SD & T & df & p \\
\hline $\begin{array}{l}\text { Concerns about own } \\
\text { security }\end{array}$ & Male & 34.67 & 10.05 & 2.785 & 262 & 0.006
\end{tabular}

A non-parametric test was used to track differences in concerns about own security regarding different demographic factors. It was elected Kruskal-Wallis Test because of the nonsymmetrical distribution. The only significant difference was registered in the case of different places of residence (village, town, capital). The analyses show that police officers who lived in the capital have higher concerns about own security $(M R=149.10)$. For the entire sample, the differences were not statistically significant, although there was a tendency police officers with a bachelor degree to have higher concerns about own security compared with police officers with secondary and master degree. Married and divorced participants have higher values of concerns about own security compared with single police officers and those in cohabitation (Table 4).

Table 4. Results from nonparametric test of Kruskal-Wallis for finding significant differences in concerns about own security in relation of demographic factors

\begin{tabular}{|c|c|c|c|c|c|c|}
\hline & $\begin{array}{l}\text { Place of } \\
\text { residence }\end{array}$ & $\mathbf{N}$ & MR & $\mathbf{X}^{2}$ & df & $\mathbf{p}$ \\
\hline \multirow[t]{3}{*}{$\begin{array}{l}\text { Concerns about own } \\
\text { security }\end{array}$} & $\begin{array}{c}\text { Village }</= \\
5,000\end{array}$ & 68 & 140.05 & \multirow{3}{*}{6.651} & \multirow{3}{*}{2} & \multirow{3}{*}{0.036} \\
\hline & $\begin{array}{c}\text { Town }</= \\
100,000\end{array}$ & 134 & 120.05 & & & \\
\hline & Capital & 62 & 149.10 & & & \\
\hline & Education & $\mathbf{N}$ & MR & $\mathbf{X}^{2}$ & df & $\mathbf{p}$ \\
\hline \multirow{4}{*}{$\begin{array}{l}\text { Concerns about own } \\
\text { security }\end{array}$} & Secondary & 66 & 134.04 & \multirow{3}{*}{1.584} & \multirow{3}{*}{2} & \multirow{3}{*}{0.453} \\
\hline & Bachelor degree & 92 & 139.23 & & & \\
\hline & Master degree & 106 & 125.70 & & & \\
\hline & Marital status & $\mathbf{N}$ & MR & $\mathbf{X}^{2}$ & df & $\mathbf{p}$ \\
\hline \multirow{4}{*}{$\begin{array}{l}\text { Concerns about own } \\
\text { security }\end{array}$} & Single & 42 & 128.13 & \multirow{4}{*}{0.720} & \multirow{4}{*}{3} & \multirow{4}{*}{0.869} \\
\hline & Cohabitation & 72 & 130.29 & & & \\
\hline & Marriage & 123 & 132.97 & & & \\
\hline & Divorced & 27 & 143,06 & & & \\
\hline
\end{tabular}


As could be seen from table 5 , there is low but significant correlation between the age of the respondents and the concerns about out security $(r=0.146 ; p=0.018)$. Almost the same values is viewed from the column about years of work experience as police officer and concerns about own security $(\mathrm{r}=0.133 ; \mathrm{p}=0.030)$.

Table 5. Results from Pearson Correlation for finding lineal connection between age, years of work experience and concerns about own security

\begin{tabular}{lcc}
\hline & \multicolumn{2}{c}{ Concerns about own } \\
& $\mathbf{r}$ & $\mathbf{p}$ \\
\hline Age & 0.146 & 0.018 \\
$\begin{array}{l}\text { Work experience as a police officer } \\
\text { (years) }\end{array}$ & 0.133 & 0.030 \\
\hline
\end{tabular}

\section{Discussion}

This paper began by arguing that concern about own security is a phenomenon that is directly related to the fear of crime, anxiety and worry. It is difficult to determine the exact boundary between these phenomena due to the vastness of the human psyche. However, there should be no doubt that the presence of such experiences leads to a decrease in well-being, ability to work and quality of life. Concerns about own security was found at middle and high levels among police officers, who participate in this study. Factors can be numerous - bad lifestyle, personal and economic difficulties, but given the peculiarities of working as a police officer, it is reasonable to assume that this is a leading factor.

In addition, this research was aimed to test for differences in concerns about own security among police officers in relation to some demographic factors. In the first place, this study examined whether differences in concerns in own security were different among police officers with different gender and age. The statistical analysis shows that women have higher values of concerns about their own security than men do. The research on fear of crime shows that women have higher levels of fear of crime, even though their levels of victimization are lower than men (Clemente \& Kleiman, 1977; Madriz, 1997). Some scholars have reported that women's fear of crime is a result of situations with a variety of acts of aggression committed by male assailants, such as intimidation and violence against women (Gordon \& Riger, 1991; Franklin \& Franklin, 2009), and as result of their perception about vulnerability which includes the fear of rape and other crimes with a sexual character (Fisher \& Sloan, 2003; Wilcox, Jordan \& Pritchard, 2006; Franklin \& Franklin, 2009). Can it be argued that this statistical result is an effect of the perception of concepts of social roles of men and women?

In second place, the research also identified significant differences between concerns about own security and place of residence. Statistical analysis show that police officers, who live in capital have higher concerns about own security than police officers, who live in other places of residence. These results lead to numerous questions. First is about the nature of concern. Is the concern an outcome of the criminogenic conditions, which appear to flourish in a capital environment, or it is a product of the feeling of depersonalization in the big city?

The results of the study revealed a weak proportional relationship between age and concern about own security among police officers. This result can be summarized as a tendency for older police officers to concern more than younger ones. Similar data are reported by other studies on fear of crime, which indicates that women and older persons are highly afraid of crime (Braungart, Braungart \& Hoyer, 1980; LaGrange \& Ferraro, 1989; Greve, Leipold \& Kappes, 2018). 


\section{Conclusion}

In conclusion, it can be noted that concerns about own security are found at high levels among police officers. The literature analysis shows that high levels of concerns can lead to impaired well-being and ability to work and reduce quality of life. Concerns about own security is very close stage to worry and anxiety

Ensuring the professional safety of police officers is a complex problem, the solution of which depends on a large number of both objective and subjective factors. In this regard, a lot of work is required on the part of managers to provide quality psychological services on the one hand, and police officers personally to take care of their mental health. It is advisable for police officers periodically resort to the methods of psychology and psychotherapy in order to reduce the feeling of concerns about their own security. This in turn will help for reduce stress, anxiety and increase performance.

\subsection{Limitations and future implications}

The main limitation is the small and unequal sample and the fact that "concerns about own security" are explorable only in relation to socio-demographic factors.

It is recommended for future research to study more mental phenomena and personal characteristics in order to enrich the knowledge about the dynamics of the phenomena "concerns about own security”.

\section{Acknowledgements}

This research did not receive any specific grant from funding agencies in the public commercial, or not-for-profit sectors.

The author declares no competing interests.

\section{References}

Agolla, J. E. (2009). Occupational stress among police officers. The case of Botswana police service, Research Journal of Business Management, 2(1), 25-35.

American Psychiatric Association (2013). Diagnostic and statistical manual of mental disorders (DSM$5 \circledR)$. American Psychiatric Pub.

Beck, A. T., \& Clark, D. A. (1997). An information processing model of anxiety: Automatic and strategic processes. Behaviour Research and Therapy, 35(1), 49-58.

Borkovec, T. D. (1994). The nature, functions, and origins of worry. In G. C. L. Davey \& F. Tallis (Eds.), Wiley series in clinical psychology. Worrying: Perspectives on theory, assessment and treatment (pp. 5-33). John Wiley \& Sons.

Borkovec, T. D., Ray, W. J., \& Stöber, J. (1998). Worry: A cognitive phenomenon intimately linked to affective, physiological, and interpersonal behavioral processes. Cognitive Therapy and Research, 22(6), 561-576. https://doi.org/10.1023/A:1018790003416

Braungart, M., Braungart, R., \& Hoyer, W. (1980). Age, sex, and social factors in fear of crime. Sociological Focus, 13(1), 55-66. Retrieved July 5, 2021, 
Button, M. (1999). Private security and its contribution to policing: under-researched, under-utilised and underestimated. International Journal of Police Science \& Management, 2(2), 103-116.

Clemente, F., \& Kleiman, M. (1977). Fear of Crime in the United States: A Multivariate Analysis. Social Forces, 56(2), 519-531. https://doi.org/10.2307/2577738

Covington, J., \& Taylor, R. (1991). Fear of Crime in Urban Residential Neighborhoods: Implications of Between- and Within-Neighborhood Sources for Current Models. The Sociological Quarterly, 32(2), 231-249.

Fisher, B. S., \& Sloan III, J. J. (2003). Unraveling the fear of victimization among college women: Is the "shadow of sexual assault hypothesis" supported? Justice Quarterly, 2O(3), 633-659.

Flouri, E., \& Panourgia, C. (2014). Negative automatic thoughts and emotional and behavioural problems in adolescence. Child and Adolescent Mental Health, 19(1), 46-51.

Folkman, S. (1984). Personal control and stress and coping processes: a theoretical analysis. Journal of personality and social psychology, 46(4), 839.

Franklin, C. A., \& Franklin, T. W. (2009). Predicting fear of crime: Considering differences across gender. Feminist Criminology, 4(1), 83-106.

Galanis, P., Fragkou, D., Kaitelidou, D., Kalokairinou, A., \& Katsoulas, T. A. (2019). Risk factors for occupational stress among Greek police officers. Policing: An International Journal, 42(4), 506-519.

Ganchevski, B., Gaydarov, K., Stamenkova, N., Zanev, S. (1996). Police psychology. Theoretical aspects [Politseyska psihologia. Teoretichni aspekti]. Sofia: Svyat i nauka

Gordon, M., \& Riger, S. (1991). The female fear: The social cost of rape. Urbana: University of Illinois Press.

Greve, W., Leipold, B., \& Kappes, C. (2018). Fear of crime in old age: a sample case of resilience? The Journals of Gerontology: Series B, 73(7), 1224-1232.

Hale, C. (1996). Fear of crime: A review of the literature. International review of Victimology, 4(2), 79-150.

Husain, W. (2019). Depression, Anxiety, and Stress Among Urban and Rural Police Officers. Journal of Police and Criminal Psychology, 1-5.

Johnson O., Russo C., Papazoglou K. (2019). Job exposure \& occupational challenges: the importance of mindfulness for today's law enforcement professional. Crisis Stress Hum. Resil. Int. J. 1, 187191.

LaGrange, R. L., \& Ferraro, K. F. (1989). Assessing age and gender differences in perceived risk and fear of crime. Criminology, 27(4), 697-720.

Lazarus, R. S. (1991). Emotion and adaptation. Oxford University Press.

Madriz, E. (1997). Images of criminals and victims: A study on women's fear and social control. Gender and Society, 11(3), 342-356. Retrieved June 29, 2021, from http://www.jstor.org/stable/190406.

Maran D., Varetto A., Zedda M., Ieraci V. (2015). Occupational stress, anxiety and coping strategies in police officers. Occup. Med. 65, 466-473. https://doi.org/10.1093/occmed/kqvo6o

Maslow, A. H. (1943). A theory of human motivation. Psychological Review, 5o, 370-396.

Maslow, A. H. (1987). Motivation and personality (3rd ed.). Harper \& Row Publishers.

Murray, H. (1981). Endeavors in psychology: Selections from the personology of Henry Murray. New York: Harper and Row.

Queirós, C., Passos, F., Bártolo, A., Marques, A. J., da Silva, C. F., \& Pereira, A. (2020). Burnout and stress measurement in police officers: literature review and a study with the operational police stress questionnaire. Frontiers in psychology, 11.

Radoslavova, M., \& Velichkov, A. (2005). Metodi za psihodiagnostika [Methods for psychodiagnostics]. Pandora prim. 
E. V. Zaimova - Tsaneva - Concerns About own Security Among Police Officers in Relation to ...

Roemer, L., \& Borkovec, T. D. (1993). Worry: Unwanted cognitive activity that controls unwanted somatic experience. In D. M. Wegner \& J. W. Pennebaker (Eds.), Handbook of mental control (pp. 220238). Prentice-Hall, Inc.

Segerstrom, S. C., Tsao, J. C., Alden, L. E., \& Craske, M. G. (2000). Worry and rumination: Repetitive thought as a concomitant and predictor of negative mood. Cognitive Therapy and Research, 24(6), 671-688.

Spielberger, C. D. (Ed.). (2013). Anxiety and behavior. Academic Press.

Toffler, A. (2002). Shok budushhego [Future shock]. Moscow: AST.

Ustinova, L. G., \& Sultanova, M. V. (2018). [Lichnaya professionalynaya bezopasnosty sotrudnikov OVD: struktura i soderzhanie]. Mir nauki, kulyturb, obrazovania, (2 (69)).437-439.

VandenBos, G. R. (Ed.). (2015). APA dictionary of psychology (2 ${ }^{\text {nd }}$ ed.). American Psychological Association.

Velichkov, A. (2004). Personal security in the big city. Socio-psychological aspects [Lichnata sigurnost v golemia grad. Sotsialnopsihologichni aspekti]. Sofia: Albatros

Wagner, S., White, N., Matthews, L. R., Randall, C., Regehr, C., White, M., ... \& Fyfe, T. (2019). Depression and anxiety in policework: a systematic review. Policing: An International Journal.

Wells, A. (2004). A cognitive model of GAD. Generalized anxiety disorder: Advances in research and practice, 164-186.

Wendt, A. (1992). Anarchy is what states make of it: The social construction of power politics. International Organization, 46(2), 391-425. https://doi.org/10.1017/S0020818300027764

Wilcox, P., Jordan, C. E., \& Pritchard, A. J. (2006). Fear of acquaintance versus stranger rape as a "master status": Towards refinement of the "shadow of sexual assault". Violence and Victims, 21(3), 355-370.

Zhong, C., \& Lijuan, A. (2004). Developing of security questionnaire and its reliability and validity. Chinese Mental Health Journal, 18(2), 97-99.

Zotova, O. Y., \& Karapetyan, L. V. (2018) Psychological security as the foundation of personal psychological wellbeing (analytical review). Psychol. Russ. State Art 2018, 11, 100-113.

Zotova, O. Yu. (2011). Bezopasnost' lichnosti kak social'no-psihologicheskij fenomen [Personality Security as a Socio-psychological Phenomenon]. Yekaterinburg: Liberal Arts University for Humanities. 